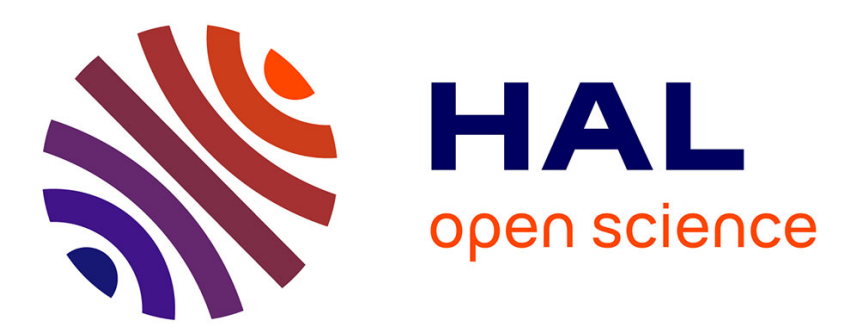

\title{
Are Clay Minerals a Significant Source of Si for Crops? A Comparison of Amorphous Silica and the Roles of the Mineral Type and pH
}

\author{
Catherine Keller, Muhammad Rizwan, Jean-Dominique Meunier
}

\section{- To cite this version:}

Catherine Keller, Muhammad Rizwan, Jean-Dominique Meunier. Are Clay Minerals a Significant Source of Si for Crops? A Comparison of Amorphous Silica and the Roles of the Mineral Type and pH. Silicon, 2021, 10.1007/s12633-020-00877-5 . hal-03167062

\section{HAL Id: hal-03167062 \\ https://hal.science/hal-03167062}

Submitted on 8 Oct 2021

HAL is a multi-disciplinary open access archive for the deposit and dissemination of scientific research documents, whether they are published or not. The documents may come from teaching and research institutions in France or abroad, or from public or private research centers.
L'archive ouverte pluridisciplinaire HAL, est destinée au dépôt et à la diffusion de documents scientifiques de niveau recherche, publiés ou non, émanant des établissements d'enseignement et de recherche français ou étrangers, des laboratoires publics ou privés. 


\section{Are clay minerals a significant source of Si for crops? A comparison of}

\section{2 amorphous silica and the roles of the mineral type and $\mathrm{pH}$}

3 Catherine Keller ${ }^{1 *}$, Muhammad Rizwan ${ }^{2}$, Jean-Dominique Meunier ${ }^{1}$

4

${ }^{1}$ Aix-Marseille Univ, CNRS, IRD, Coll de France, INRAE, CEREGE, Technopole de l'Environnement Arbois-

Méditerranée, BP80, 13545 Aix-en-Provence, Cedex 4, France

${ }^{2}$ Department of Environmental Sciences and Engineering, Government College University, Faisalabad 38000, Pakistan

9

*Corresponding author: keller@cerege.fr

Keywords: clay minerals, diatomite, $\mathrm{pH}$, rice, silicon, wheat

\section{Declarations}

4. Code availability: NA

1. Fundings: the fundings are detailed in the Acknowledgement and explain that this work was financed by the French INSU (Institut National des Sciences de l'Univers, CNRS) programme EC2CO (Ecosphère continentale et côtière), the BIOSiSOL project (ANR-14-CE01-0002) and by the Indo-French Centre for the Promotion of Advanced Research (IFCPAR/CEFIPRA project $\left.n^{\circ} 5109-1\right)$.

2. Conflicts of interest/competing interests: The authors declare that they have no conflict of interest.

3. Availability of data and material: data available and original material as well

\section{Acknowledgement}


25 This work was financed by the French INSU (Institut National des Sciences de l'Univers, CNRS)

26 programme EC2CO (Ecosphère continentale et côtière), the BIOSiSOL project (ANR-14-CE01-

27 0002) and by the Indo-French Centre for the Promotion of Advanced Research (IFCPAR/CEFIPRA

28 project $\left.\mathrm{n}^{\circ} 5109-1\right)$. We thank Haider Allami and Jing Sha, MSc, for their work on the project, N.B.

29 Prakash for his help in the selection of the rice cultivar and for providing the seeds, S. Jézéquel

30 (ARVALIS-Institut du végétal) for providing the wheat seeds and Sibelco for providing quartz.

31 BET was measured at MADIREL, Aix-Marseille Univ, France.

32

33 


\section{Abstract}

Identifying the source(s) of silicon (Si) for plant is a key issue in understanding the terrestrial cycle of Si and for deciphering the reservoir of bioavailable Si to Si accumulating crops. In soils, amorphous $\mathrm{Si}$, one of the most bioavailable source, is mostly present as phytoliths and has been suggested for use as a Si fertilizer by diatomite application. Although clay minerals are known to contribute to plant nutrition, their role as a major source of silica for plants has not been fully addressed. We aim at evaluating the efficiency of clay minerals as a source of Si for crops.

We conducted two pot experiments: one wheat-growing experiment to compare a clay (vermiculitic) mineral and amorphous silica particles (diatomite, which is used as a phytolith substitute), and one rice-growing experiment to compare two types of clay (kaolinite vs montmorillonite) common in rice cultivation.

We confirmed that the amorphous silica was more efficient than vermiculite for Si uptake by wheat. However, the Si uptake was not significantly different between the $5 \%$ diatomite substrate and the $25 \%$ vermiculite substrate indicating that clays may challenge amorphous silica, as a source of Si for crops. The kaolinite probably delivered less $\mathrm{Si}$ to the rice than the montmorillonite because of the lower specific surface area and lower $\mathrm{pH}$ of kaolinite substrates. Because clays are generally much more abundant in soils than amorphous silica, we concluded that clays may be a substantial Si source for plants, depending on the clay mineralogy. 


\section{Introduction}

Recognition of the importance of plant cycling in the global silicon (Si) cycle [1] and the increased body of evidence demonstrating that $\mathrm{Si}$ is a beneficial element in agriculture $[2,3]$ have stimulated research on $\mathrm{Si}$ in the context of increasing food demand [4]. Silicon is not considered as a nutrient but many studies show that at low Si concentration, many crops have lower development and yield $[2,5,6]$. Common crops such as rice and wheat are considered as Si accumulators while rice has a higher Si requirement than wheat [7]. They accumulate Si mostly in the shoots through the uptake of dissolved Si from the soil. The accumulation of Si in plants is therefore highly dependent on the bioavailability of Si in soil [2]. The Si bioavailability ultimately depends on the reactivity (solubility and rate of dissolution) of the silicate minerals present in soils, which include aluminosilicates, crystalline silica minerals (e.g. quartz) and amorphous silica particles. Amorphous silica particles are mostly present as phytoliths, which are the form of Si that is accumulated in plants and is reincorporated into the soil during litter decomposition. Based on laboratory experiments, it has been shown that phytoliths are 2 to 4 orders of magnitude more reactive than primary mafic silicates and feldspar as well as secondary clay minerals [8]. The higher solubility of phytoliths supports models of the terrestrial biogeochemical Si cycle that show the importance of plant Si recycling $[1,9]$. Typically, the amount of phytoliths in soils is approximately $1 \%$ soil dry weight (DW) [10], and Si in phytoliths initially originates from the slow dissolution of primary minerals at different rate depending on the environmental conditions including the soil type [11].

In some parts of the world soils may be acidic and depleted in primary silicate minerals leading to low values of phytoavailable Si [12] and/or croppings may have led to exhaustion of phytoavailable Si [5]. In this type of situation, Si fertilization has been found to increase crop 
yields $[2,5,13]$. The materials used as Si fertilizers are varied, but some contain or are composed of amorphous silica either as phytoliths (e.g. biochar see [14]) or as diatomite [13, 15]. Clay minerals are present in various amounts and in different types in cultivated soils depending on the degree of soil weathering and the climate [11]. They play a major role in plant nutrition by providing large specific surface areas that can fix nutrients [16]. There is evidence in the literature that clay mineral structures may be affected by plants. Cornu et al. [17] compared the evolution of the clay composition between forested and cultivated soils and showed that the lower $\mathrm{pH}$ under forest led to quicker clay dissolution and aluminum release. More recently, it was shown at Morrow plot experiment field (USA) that continuous cropping for 110 years led to an increase in fine clay particles $(<0.05 \mathrm{~mm})$ [18], which is an indicator of clay mineral dissolution. In a rice paddy field in Camargue (France), the decreased crystallinity of smectite was attributed to rice cultivation and its subsequent Si uptake [19]. However, no associated Si concentrations in plants were reported in that study, or in the other abovementioned studies. Some data show that Si bioavailability was correlated with clay content $[2,20]$, although a recent study in South India did not confirm this statement [21]. Si isotopes were used to trace the origin of Si in southern Indian soil solution from forested and cultivated areas, and the authors found that input from clays could be neglected compared to amorphous silica $[22,23]$. It has been found that natural prairie ecosystems in California extracted larger proportion of biogenic Si (Si solubilized from phytoliths) from the topsoil but also took up Si from poorly crystalline secondary silicates that were solubilized at depth [24].

The objective of this paper is therefore to document the contribution of clays to crop uptake compared to amorphous silica using pot experiments. Our hypothesis is that clay minerals may constitute a significant Si source because their abundance in soils (ca. 10\% DW or more) may compensate for their lower solubility compared to phytoliths, the abundance of which is 
generally low (below 1\%) [25]. For this purpose, we conducted two pot experiments using rice

102

103

104

105 that are used to cultivate rice [12].

106

\section{7}

108

109

110

\section{Materials and methods} and wheat, first, to compare the Si uptake from quartz (as an inert material), a clay mineral and an amorphous Si substrate (diatomite), and second, to evaluate the roles of two clay minerals, kaolinite and smectite, which are typical clay minerals in acidic and neutral soils, respectively,

\subsection{Pot experiment 1 (exp.1) with wheat (Triticum turgidum L. cv. Claudio W.)}

Three types of materials were used, that is, quartz, vermiculite and diatomite. Quartz $(99.87 \%$ $\mathrm{SiO}_{2}$, Sibelco, France), which was further cleaned and sieved with dilute nitric acid and rinsed with distilled water to remove impurities, was selected as the reference inert material. The cleaned quartz was mixed with a vermiculitic clay (Vermica AG, Bözen, Switzerland) or diatomite (Clarcel 78, CECA) in different proportions on a \% dry weight (DW) basis for (diatomite or vermiculite) /quartz ratios of [25/75], [15/85], and [5/95]. Diatomite was used as a source of amorphous Si and as a proxy for phytoliths based on the following assumptions: 1) the solubility of phytoliths does not differ from that of amorphous Si [8]; 2) the dissolution rates of phytoliths and diatomaceous lake sediments fall within the same range [26]; and 3) the specific surface areas of phytoliths and diatoms, although highly variables, fall within the same ranges of 5-315 $\mathrm{m}^{2} \mathrm{~g}^{-1}$ and $25-250 \mathrm{~m}^{2} \mathrm{~g}^{-1}$ for phytoliths [8, 27] and diatoms [28], respectively. Assuming that diatomite is equivalent to phytoliths in terms of the amount and form of $\mathrm{Si}$, our experiments using 5 to $25 \%$ diatomite over-estimated the average amount of phytoliths in the soil, which is generally below $1 \%$, but they were compatible with the cases reported in the literature $[29,30]$. We chose $5 \%$ as a minimum value in our experiment because using $1 \%$ diatomite would have 
been difficult to mix homogeneously while the \% of clay used was within the range of the clay amount found in agricultural soils.

\subsection{Pot experiment 2 (exp.2) with rice (Oryza sativa L., cv. Anagha)}

129 Three types of silicate were used, namely quartz (similar to experiment 1), which was mixed with 2 different clay minerals: montmorillonite was used because it is a common mineral in the smectite group (natural montmorillonite, Aroma-Zone, France) and kaolinite (Merck, Germany). We tried to grow rice on a substrate containing only quartz, and we used mixtures of clays with quartz in the following proportions: (vermiculite or kaolinite)/quartz in DW \% = [35/65], [25/75] 134 and [15/85].

\subsection{Experimental and analytical conditions}

137 The purity of the materials was verified using X-ray diffraction (Philips PW3710 at $30 \mathrm{kV}$ and 10 $138 \mathrm{~mA}$ ). The specific surface of the initial materials was also measured (3flex, Microméritics, 139 adsorption measured in the $\mathrm{BET}$ range $0.05<\mathrm{p} / \mathrm{p}^{\circ}<0.3$ ). For both pot experiments, $400-\mathrm{ml}$ plastic 140 pots were prepared, each of which contained $300 \mathrm{~g}$ of the prepared substrates and they were 141 tested in 3 (exp. 1) or 5 (exp. 2) replicates with 4 plants per pot and in 2 (exp. 1) or 3 (exp. 2) 142 replicates without plants. All the plastic and glassware was rinsed with $10 \% \mathrm{HNO}_{3}$. Initially, the 143 pots were seeded at a density of six seeds per pot and the seedlings were thinned to four 144 individuals per pot at five days after germination. Each pot was fertilized with a $1 / 4$ Hoagland 145 solution (without Si) and watered to keep substrates at water holding capacity (WHC). The 146 plants were grown under controlled conditions with a short-day cycle $\left(8 / 16 \mathrm{~h} 23{ }^{\circ} \mathrm{C} / 20^{\circ} \mathrm{C}\right.$ 147 day/night), $70 \%$ humidity and $187 \mu \mathrm{mol}$ photon $\mathrm{m}^{-2} \mathrm{~S}^{-1}$ of light intensity. The pots were 148 randomly rotated and the weeds were removed regularly when present. The plants were 
harvested after 60 days by cutting the shoots approximately one centimeter above the substrate surface. Plant samples were washed with distilled water and oven dried at $70{ }^{\circ} \mathrm{C}$ until

151 reaching a constant weight. The shoot dry weights were measured and the shoots were then

152 ground into powder. The $\mathrm{pH}$ values of the various substrates were measured in water before

153 and after plant growth (ratio 1:2.5). The Si concentration in the plant shoots was obtained using

$1541 \% \mathrm{Na}_{2} \mathrm{CO}_{3}$ extraction followed by colorimetric determination [31] or using Tiron extraction

155 [32]. For exp. 2, one Rhizon ${ }^{\circledR}$ (Rhizosphere Research Products bv, NL) was installed in each pot.

156 Soil solutions were collected after 4 and 7 weeks of growth, and the Si concentration (DSi) was

157 measured by colorimetry [31].

158 All the data were statistically analyzed using a one-way ANOVA. Then, a post-hoc test of 159 pairwise multiple comparisons of Fisher (LSD) was performed on the different parameters to 160 assess if their various levels were significantly different from each other, at a significance level 161 of $\mathrm{P}<0.05$ with XLSTAT software for Windows.

162

163

\section{Results}

164

165 The X-ray diffractogram showed no impurities in the quartz material, while the vermiculite clay was composed of a mixture of vermiculite with vermiculite-illite, regular smectite-illite

167 interlayers and irregular illite-smectite interlayers. The presence of smectite and quartz was 168 detected in the diatomite, feldspar, quartz and illite were detected in the kaolinite material and 169 illite, feldspar, carbonates and gypsum were found in the montmorillonite material. The specific 170 surfaces were $0.01 \mathrm{~m}^{2} \mathrm{~g}^{-1}$ for quartz, 4.3 et $7.6 \mathrm{~m}^{2} \mathrm{~g}^{-1}$ for the diatomite and the vermiculite 171 respectively and, 123 and $10 \mathrm{~m}^{2} \mathrm{~g}^{-1}$ for the montmorillonite and the kaolinite, respectively. 
172 For wheat (exp.1), the results showed that the Si was significantly higher in the shoots grown

173 on diatomite substrates than in shoots grown on vermiculite substrates (Table 1); the shoot

174 biomass was significantly higher on the $25 \%$ diatomite substrate than on other substrates

175 showing that below $25 \%$ diatomite, the nature of the substrate had no effect on the biomass

176 (Figure 1, Table 1). The uptake or mineralomass of Si (Table 1), showed that diatomite

177 substrates accumulated more Si than vermiculite substrates in general. However, the Si uptake

178 from the $5 \%$ diatomite substrate and on the $25 \%$ vermiculite substrate were not significantly

179 different.

180 The $\mathrm{pH}$ was significantly higher on vermiculite substrates (approximately 9 ) than on diatomite

181 substrates (approximately 5), with $\mathrm{pH}$ values decreasing with increasing proportions of 182 diatomite and with plants. $\mathrm{pH}$ did not significantly change in the vermiculite modality. The $\mathrm{pH}$ 183 of vermiculite and smectite may range from acidic to alkaline. Alkaline values may be attributed 184 to impurities such as carbonates or to the types of exchangeable cations ( $\mathrm{Ca}^{2+}$ being more acidic 185 than $\left.\mathrm{Na}^{+}[33]\right)$. Surprisingly, the Si concentration in the wheat shoots grown on vermiculite 186 substrates was not negligible. However, the Si concentration in the shoots was significantly 187 higher on the diatomite substrates $\left(17-25 \mathrm{~g} \mathrm{Si} \mathrm{kg}^{-1}\right)$ than on those containing vermiculite (8-13 $188 \mathrm{~g} \mathrm{Si} \mathrm{kg}^{-1}$ ) with a trend towards higher values at higher proportions of diatomite or vermiculite 189 (Table 1).

190

191 For rice (exp. 2), the results showed a significantly higher Si concentration and Si uptake in 192 shoots grown on the montmorillonite substrates than in the shoots grown on kaolinite 193 substrates (Table 2). The shoot biomass was the highest on the $35 \%$ montmorillonite substrates 194 and on the $35 \%$ kaolinite substrate (Figure 1). The $\mathrm{pH}$ was acidic in the soil solutions of the 195 kaolinite substrates, near neutral in that of the $100 \%$ quartz substrate and alkaline in the soil 
solutions of the montmorillonite substrates and all slightly lower than the respective $\mathrm{pH}$ of the

197 initial substrates. The plants grown on the $100 \%$ quartz substrate did not survive after 2 weeks, 198 possibly because the sandy texture was not favorable to rice growth [34] as rice requires 199 partially saturated clay soil. The silicon concentration in the soil solution increased with time in 200 the pots without plants, regardless of the clay mineral. It decreased when the pots were 201 planted, indicating Si depletion through Si uptake. However, although the plants went on 202 growing between 4 and 7 weeks, the Si concentration in the soil solution was higher after 7 203 weeks than after 4 weeks of growth, indicating continuous dissolution in both the 204 montmorillonite and the kaolinite pots.

\section{Discussion}

The Si concentration of the wheat shoots (experiment 1) fell within the lower range of 21 durum wheats (13-33 $\mathrm{g} \mathrm{Si} \mathrm{kg}^{-1}$ ) [35] although the concentrations were lower in wheat grown on vermiculite. Our data confirmed that amorphous silica is a better source of Si for plant uptake than clay minerals as stated by [8]. The difference between the 2 sources was explained by the higher reactivity (solubility, rate of dissolution) of amorphous silica, while BET was similar. The acidic $\mathrm{pH}$, which resulted from the mixture of diatomite, quartz and nutrient solution, allowed

214 for amorphous silica dissolution and its uptake by plants, as shown by Sandhya et al. [13] who 215 demonstrated the positive effect of diatomaceous earth applications on acidic soils in southern 216 India for rice. The fact that the Si uptake by wheat was not significantly different between the $2175 \%$ diatomite substrate and the $25 \%$ vermiculite substrate (Table 1 ) indicated that clays may 218 challenge amorphous silica as a source of Si for crops. However, 5\% amorphous silica is rarely 219 found in nature. To estimate how much diatomite would be required to fit the Si concentration 
measured on the vermiculite mixtures, a regression analysis was performed using the data from

221 the diatomite pots, assuming that at $0 \%$ diatomite (or 100\% quartz), the Si concentration in the 222 shoots would be negligible.

223 The curve should pass through 0 if there were no Si source in the system. In the experiment,

224 this is not the case for several reasons: first, there is always a tiny amount of Si in seeds that may be reallocated to shoots; second, we assumed that $100 \%$ of quartz is crystalline and thus

226 should not provide Si to the system. However, impurities less than 5\% and amorphous Si 227 induced by grinding cannot be detected by DRX. This is indeed visible in the soil solution 228 collected in the $100 \%$ Quartz pot with rice. But we consider that the limited impact of these experimental biases does not prevent calculation of a theoretical regression curve using 0 as 230 the origin for $0 \%$ diatomite.

231 We found that the data fitted a hyperbola-type regression (Figure 2) described as follows:

$$
\text { Si shoots concentration }(\mathrm{g} / \mathrm{kg})=(\mathrm{m} * \% \text { diatomite }) /(\mathrm{k}+\% \text { diatomite })
$$

233 with $\mathrm{m}(=26.8)$ and $\mathrm{k}(=2.79)$, the two constants that were calculated using the transformation 234 of eq. 1 into the following linear equation:

(2) $\quad 1 / \mathrm{Si}$ shoots concentration $(\mathrm{g} / \mathrm{kg})=1 / \mathrm{m}+(\mathrm{k} / \mathrm{m}) *(1 / \%$ diatomite $)$

237 Accordingly, to obtain the equivalent of $13 \mathrm{~g} \mathrm{Si} \mathrm{kg}^{-1}$ in shoot, which was the maximum 238 concentration found using $25 \%$ vermiculite (Table 1, Figure 2), we estimated that $2.6 \%$ 239 diatomite would be required. Following the same line of reasoning, we calculated the amount 240 of vermiculite required to match $1 \%$ phytoliths, a current concentration found in soils, assuming 241 that diatomite is a proxy for phytoliths. We obtained $5 \%$ vermiculite for a concentration of 7.7 $242 \mathrm{~g} \mathrm{Si} \mathrm{kg}^{-1}$ in shoot. The 5/1 ratio between vermiculite and phytoliths is approximately the same 243 as the ratio expected from the dissolution rates of clays and phytoliths [8]. 
245 In experiment 2, all the Si concentrations obtained for rice were lower than the average value 246 of $31.7 \mathrm{~g} \mathrm{Si} \mathrm{kg}^{-1}$ [7], but those in rice grown on montmorillonite fell within the range of values 247 (20-30 $\left.\mathrm{g} \mathrm{Si} \mathrm{kg}^{-1}\right)$ obtained for a rice variety grown in various southern Indian soils [36]. The Si 248 concentrations in rice shoots grown on kaolinite substrates were one order of magnitude lower 249 than most of the values found in the literature but they were within the same order of 250 magnitude as the value $\left(2.6 \mathrm{~g} \mathrm{Si} \mathrm{kg}^{-1}\right)$ found for a mutant rice variety that was defective in $\mathrm{Si}$ 251 uptake [5]. The higher Si uptake on montmorillonite substrates compared to kaolinite was 252 explained by a higher montmorillonite dissolution rate, as indicated by the higher $\mathrm{Si}$ 253 concentrations in the soil solution. However, $\mathrm{Si}$ is released from both minerals at similar rates, 254 with a similar $\mathrm{U}$ pattern according to the $\mathrm{pH}$, and with minimum rates at approximately $\mathrm{pH} 7-8$ 255 and maximum rates under acidic conditions $[37,38]$. Because the $\mathrm{pH}$ in the kaolinite substrates 256 was lower than it was in the montmorillonite substrates, while kaolinite released less $\mathrm{Si}$, pH was 257 not responsible for the larger Si release by montmorillonite. However, the reactivity also 258 depends on the surface area, which was larger for the montmorillonite $\left(123 \mathrm{~m}^{2} \mathrm{~g}^{-1}\right)$ than for the 259 kaolinite $\left(10 \mathrm{~m}^{2} \mathrm{~g}^{-1}\right)$ as reported in the literature [39]. The larger $\mathrm{Si}$ uptake from the 260 montmorillonite substrates relative to the kaolinite substrates may therefore be attributed to 261 the higher specific surface of montmorillonite particles that are releasing larger amounts of Si combined with near-neutral $\mathrm{pH}$ conditions favorable to rice growth.

263 However, from the montmorillonite substrates, the plants extracted only part of the Si present 264 in the soil solution indicating that the Si concentration in solution was not the limiting factor for 265 plant uptake (Table 2). On kaolinite substrates, the Si uptake was correlated with the Si 266 concentration in the soil solution, indicating that at this low $\mathrm{pH}$ value, the rice took up only a 267 limited amount of Si due to the unfavorable growth conditions (Figure 3A). By contrast, the 
uptake from montmorillonite substrates was correlated with the difference in Si concentrations

269 in the soil solution measured between pots without and with plants, indicating that 270 solubilization was efficient at providing enough Si to the rice plants (Figure 3B). Kaolinite and 271 montmorillonite were thus able to provide significant but different amounts of Si to plants.

272

\section{Conclusion}

274

275 The wheat experiment showed that amorphous silica performed better than vermiculite at 276 providing Si to wheat. Clays may therefore challenge amorphous silica (phytoliths) for Si 277 provision to plants, because the usually higher proportion of clay found in soils may offset their 278 lower reactivity. The finding that the equivalence between clay and amorphous silica is more in 279 favor of clay than expected from their respective dissolution rates deserves more research. The 280 rice experiment showed that montmorillonite at or near a neutral $\mathrm{pH}$ was more favorable for Si 281 uptake than kaolinite at an acidic $\mathrm{pH}$, as also found in the field [13]. The clay type and $\mathrm{pH}$ are 282 therefore two key parameters that can explain the role of clays in Si uptake by plants. 
1. Alexandre A, Meunier J-D, Colin F, Koud JM (1997) Plant impact on the biogeochemical cycle of silicon and related weathering processes. Geochim Cosmochim Acta 61:677-682

2. Liang $Y$, Nikolic $M$, Bélanger R, Gong $H$, Song A (2015) Silicon in agriculture: From theory to practice. Springer $235 p$

3. Coskun D, Deshmukh R, Sonah H, Menzies JG, Reynolds O, Ma JF, Kronzucker HJ, Bélanger RR 291 (2019) The controversies of silicon's role in plant biology. New Phytol 221:67-85

4. Luyckx M, Hausman J-F, Lutts S, Guerriero G (2017) Silicon and plants current knowledge and 293 technological perspectives, Front Plant Sci 8 article 411

5. Ma J-F, Takahashi E (2002) Soil fertilizer and plant silicon research in Japan. Elsevier

6. Guntzer F, Keller C, Meunier J-D (2012) Benefits of plant silicon for crops, a review. Agron

7. Hodson MJ, White PJ, Mead A, Broadley MR (2005) Phylogenetic variation in the silicon 298 composition of plants. Ann Bot 96:1027-1046

8. Fraysse F, Pokrovsky OS, Schott J, Meunier J-D (2009) Surface chemistry and reactivity of plant phytoliths in aqueous solutions. Chem Geol 258:197-206

9. Conley DJ (2002) Terrestrial ecosystems and the global biogeochemical silica cycle. Global Biogeochemical Cycles 16:1121, doi:10.1029/2002GB001894

10. Keller C, Guntzer F, Barboni D, Labreuche J, Meunier J-D (2012) Impact of agriculture on the 304 Si biogeochemical cycle: Input from phytolith studies. C R Geoscience 344:739-746

305 11. Cornelis J-T, Delvaux B, Georg RB, Lucas Y, Ranger J, Opfergelt S (2011) Tracing the origin of 306 dissolved silicon transferred from various soil-plant systems towards rivers a review. 

estimating plant-available Si? A case study in rice fields in Karnataka (South India). Plant Soil 432:143-155

13. Sandhya K, Prakash NB, Meunier J-D (2018) Diatomaceous earth as source of silicon on the

312 growth and yield of rice in contrasted soils of Southern India. J Soil Sci Plant Nutr 18:344-360

14. Houben D, Sonnet P, Cornelis J-T (2014) Biochar from Miscanthus a potential silicon

314 fertilizer. Plant Soil 374:871-882

15. Crooks R, Prentice P (2017) Extensive investigation into field-based responses to a silica fertilizer. Silicon 9:301-304

16. Velde B, Barré P (2010) Soils, Plants and Clay Minerals: Mineral and Biologic Interactions. Springer-Verlag Berlin Heidelberg, 249p

17. Cornu S, Montagne D, Hubert F, Barré P, Caner L (2012) Evidence of short-term clay evolution in soils under human impact. CR Geoscience 344:747-757

18. Bakker E, Hubert F, Wander MM, Lancon B (2018) Soil development under continuous agriculture at the Morrow plots experimental fields from X-ray diffraction profile modelling. Soil

323 Syst 2:46; doi103390/soilsystems2030046

324 19. Irfan K, Trolard F, Shahzad T, Cary L, Mouret J-M, Bourrié G (2017) Impact of 60 years of 325 intensive rice cropping on clay minerals in soils due to Si exportation. Am J Agric For 5:40-48 326 20. Vandevenne FI, Barao L, Ronchi B Govers G, Meire P, Kelly EF, Struyf E (2015) Silicon pools 327 in human impacted soils of temperate zones. Global Biogeochemical Cycles 29: 1439-1450 328 21. Meunier J-D, Barboni D, Anwar-ul-Haq M, Levard C, Chaurand P, Vidal V, Grauby O, Huc R, 329 Laffont-Schwob I, Rabier J, Keller C (2017) Effect of phytoliths for mitigating water stress in 330 durum wheat. New Phytol 215:229-239 
333 forested tropical watershed: Mule Hole critical zone observatory (Southern India). Geochim.

334 Cosmochim. Acta. doi.org/10.1016/i.gca.2018.02.046

335 23. Riotte J, Sandhya K, Prakash NB, Audry S, Zambardi T, Chmelef J, Buvaneshwari S, Meunier 336 J-D (2018) Origin of silica in rice plants and contribution of diatom Earth fertilization: insights 337 from isotopic Si mass balance in a paddy field. Plant Soil 423:481-501. 338 https://doi.org/10.1007/s11104-017-3535-z

339 24. White AF, Vivit DV, Shulz MS, Bullen TD, Evett RR, Aagarwal J (2012) Biogenic and pedogenic 340 controls on Si distributions and cycling in grasslands of the Santa Cruz soil chronosequence 341 California. Geochim Cosmochim Acta 94:72-94

342 25. Alexandre A, Bouvet M, Abbadie L (2011) The role of savannas in the terrestrial Si cycle a 343 case-study from Lamto Ivory Coast. Global Planet Changes 78:162-169

344 26. Loucaides S, Van Cappelen P, Behrends T (2008) Dissolution of biogenic silica from land to 345 ocean role of salinity and $\mathrm{pH}$. Limnol Oceanogr 53(4):1614-1621

346 27. Fraysse F, Pokrovsky OS, Schott J, Meunier J-D (2006) Surface properties, solubility and 347 dissolution kinetics of bamboo phytoliths. Geochimica et Cosmochimica Acta 70:1939-1951 348 28. Sarmiento JC, Gruber N (2006) Chapter 10 Oceanic carbon cycle atmospheric $\mathrm{CO}_{2}$ and 349 climate. In: Ocean biogeochemical dynamics, Princeton University Press, Princeton NJ, 99p 350 29. Meunier J-D, Colin F, Alarcon C (1999) Biogenic silica storage in soils. Geology 27:835-838 351 30. Osterrieth M, Borrelli N, Alvarez MF, Fernández Honaine M (2015) Silica biogeochemical 352 cycle in temperate ecosystems of the Pampean Plain, Argentina. Journal of South American 353 Earth Sciences 63:172-179 

of the wet alkaline procedure used to quantify the amorphous silica fraction (ASi) in soils and continental waters. Geoderma 216:30-35

32. Guntzer F, Keller C, Meunier J-D (2010) Determination of the silicon concentration in plant material using Tiron extraction. New Phytol 188:902-906

33. Kaufhold S, Dohrmann R, Koch D, Houben G (2008) The pH of aqueous bentonite suspensions. Clays Clay Miner 56:338-343

34. Dou F, Soriano J, Tabien RE, Chen K (2016) Soil texture and cultivar effects on rice (Oryza sativa $L$.) grain yield yield components and water productivity in three water regimes. PLoS ONE 11 e0150549 doi101371/journal pone0150549

35. Merah O, Deléens E, Monneveux P (1999) Grain yield carbon isotope discrimination mineral and silicon content in durum wheat under different precipitation regimes. Physiol Plant 107:387-394

36. Narayanaswamy C, Prakash NB (2009) Calibration and categorization of plant available 368 silicon in rice soils of South India. J Plant Nutr 32:1237-1254

37. Rozalen M, Huertas FH, Brady PV (2008) Experimental study of the effect of pH on the kinetics of montmorillonite dissolution at $25^{\circ} \mathrm{C}$. Geochim Cosmochim Acta 72:4224-4253 38. Huertas FJ, Chou L, Wollast R (1999) Mechanism of kaolinite dissolution at room temperature and pressure Part II Kinetic study. Geochim Cosmochim Acta 63:3261-3275 39. Umran Dogan AU, Dogan M, Inal M, Sarikaya Y, Aburub A, Wurster DE (2006) Baseline

374 studies of the clay minerals society source clays specific surface area by the Brunauer Emmett 375 Teller (BET) method. Clays Clay Miner 54:62-66 
379 Table 1 Results of the pot experiment 1 using wheat grown for 60 days on substrates composed

380 of mixtures of diatomite or vermiculite with quartz in the proportions of $25 / 75,15 / 85$ and $3815 / 95 \%$ DW. The Si concentration and biomass are from the shoots and the $\mathrm{pH}$ was measured at 382 the end of the experiment in the substrates. For each line except for $\mathrm{pH}$, different letters 383 indicate that the means are statistically different at the $\mathrm{P} \leq 005$ level. For $\mathrm{pH}$, different letters 384 indicate that the means are statistically different at the $\mathrm{P} \leq 005$ level considering all modalities, 385 with and without plants.

\begin{tabular}{|c|c|c|c|c|c|c|c|}
\hline & & \multicolumn{3}{|c|}{ Diatomite/Quartz (\%) } & \multicolumn{3}{|c|}{ Vermiculite/Quartz (\%) } \\
\hline & & $25 / 75$ & $15 / 85$ & $5 / 95$ & $25 / 75$ & $15 / 85$ & $5 / 95$ \\
\hline Shoot [Si] & Mean & $24.92 \mathrm{~A}$ & $21.80 \mathrm{~A}$ & $17.28 \mathrm{~B}$ & $13.02 \mathrm{C}$ & $10.46 \mathrm{CD}$ & $7.67 \mathrm{D}$ \\
\hline g Si kg ${ }^{-1}, \mathrm{n}=3$ & $S D$ & 1.42 & 2.16 & 1.27 & 3.38 & 1.71 & 0.62 \\
\hline Shoot biomass & Mean & $0.71 \mathrm{~A}$ & $0.55 \mathrm{~B}$ & $0.48 \mathrm{~B}$ & $0.45 \mathrm{~B}$ & $0.45 \mathrm{~B}$ & 0.44 B \\
\hline g DW $\operatorname{pot}^{-1}, \mathrm{n}=3$ & $S D$ & 0.1 & 0.11 & 0.06 & 0.08 & 0.09 & 0.04 \\
\hline Shoot Si uptake & Mean & $17.71 \mathrm{~A}$ & $11.88 \mathrm{~B}$ & $8.28 \mathrm{C}$ & $5.81 \mathrm{CD}$ & $4.61 \mathrm{D}$ & $3.36 \mathrm{D}$ \\
\hline$m g$ Si pot ${ }^{-1}, n=3$ & $S D$ & 2.25 & 2.40 & 0.95 & 1.13 & 0.40 & 0.13 \\
\hline $\mathrm{pH}$ of initial substrates & & 6.37 & 6.30 & 6.54 & 8.79 & 8.89 & 9.00 \\
\hline $\mathrm{pH}$ substrate, $\mathrm{n}=2$ & Mean & $5.01 \mathrm{~F}$ & $5.13 \mathrm{E}$ & $5.76 \mathrm{D}$ & $8.93 \mathrm{C}$ & $9.09 \mathrm{AB}$ & $9.00 \mathrm{BC}$ \\
\hline without plants & $S D$ & 0.04 & 0.01 & 0.02 & 0.01 & 0.00 & 0.13 \\
\hline $\begin{array}{l}\mathrm{pH} \text { substrate, } \mathrm{n}=3 \text {, } \\
\text { with plants }\end{array}$ & $\begin{array}{l}\text { Mean } \\
\text { SD }\end{array}$ & $\begin{array}{c}4.71 \mathrm{G} \\
0.03\end{array}$ & $\begin{array}{l}4.95 \mathrm{~F} \\
0.04\end{array}$ & $\begin{array}{l}5.20 \mathrm{E} \\
0.05\end{array}$ & $\begin{array}{c}9.12 \mathrm{~A} \\
0.02\end{array}$ & $\begin{array}{c}9.18 \mathrm{~A} \\
0.04\end{array}$ & $\begin{array}{c}9.01 \mathrm{BC} \\
0.08\end{array}$ \\
\hline
\end{tabular}


Table 2 Results of the pot experiment 2 with rice grown for 60 days in substrates composed of mixtures of montmorillonite or kaolinite with quartz in proportions of $35 / 65,25 / 75$ and $15 / 85 \%$

DW. The Si concentrations and biomass are from the shoots and the $\mathrm{pH}$ was measured at the end of the experiment in the substrates. Dissolved Si (DSi) was measured in soil solutions collected 4 and 7 weeks after sowing. For each line, different letters in each column indicate that the means are statistically different at the $\mathrm{P} \leq 005$ level, ND=not determined (no growth).

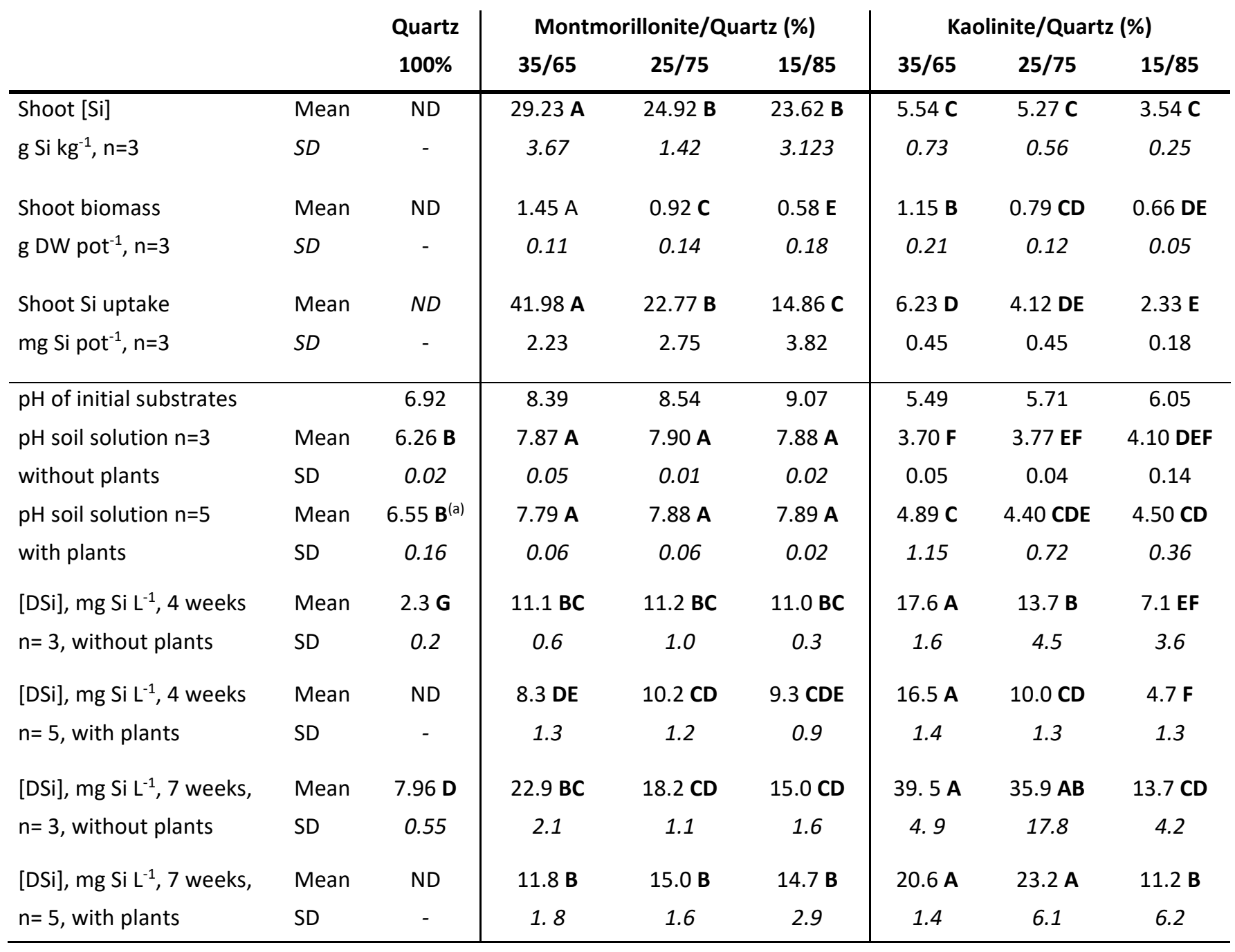




\section{Figures captions}

402

403 Fig 1 Photographs of the pot experiments 1 and 2 before harvesting for wheat $(A, B)$ and rice

404 (C, D) showing the variation of plant height according to the proportion (\% dry weight) of 405 diatomite (D) vermiculite (V), montmorillonite (M) and kaolinite (K) mixed with quartz 406

407 Fig 2 Plots of the data from experiment 1 with a hyperbola-type regression model for diatomite 408 mixtures used to estimate the amount of diatomite required (below 5\%) to match the $\mathrm{Si}$ 409 concentration in shoots grown on clay mineral (V) mixtures

410

411 Fig 3 Relationship between Si exportations by rice and Si concentrations in soil solution in 412 experiment 2 A: silicon exportation by rice shoots for the 2 types of clay minerals, 413 montmorillonite and kaolinite; B: for montmorillonite only, silicon exportation by rice shoots in 414 relation to the difference in Si concentration measured in the soil solution after 7 weeks of 415 growth between pots without and with plants 
417 Figure 1
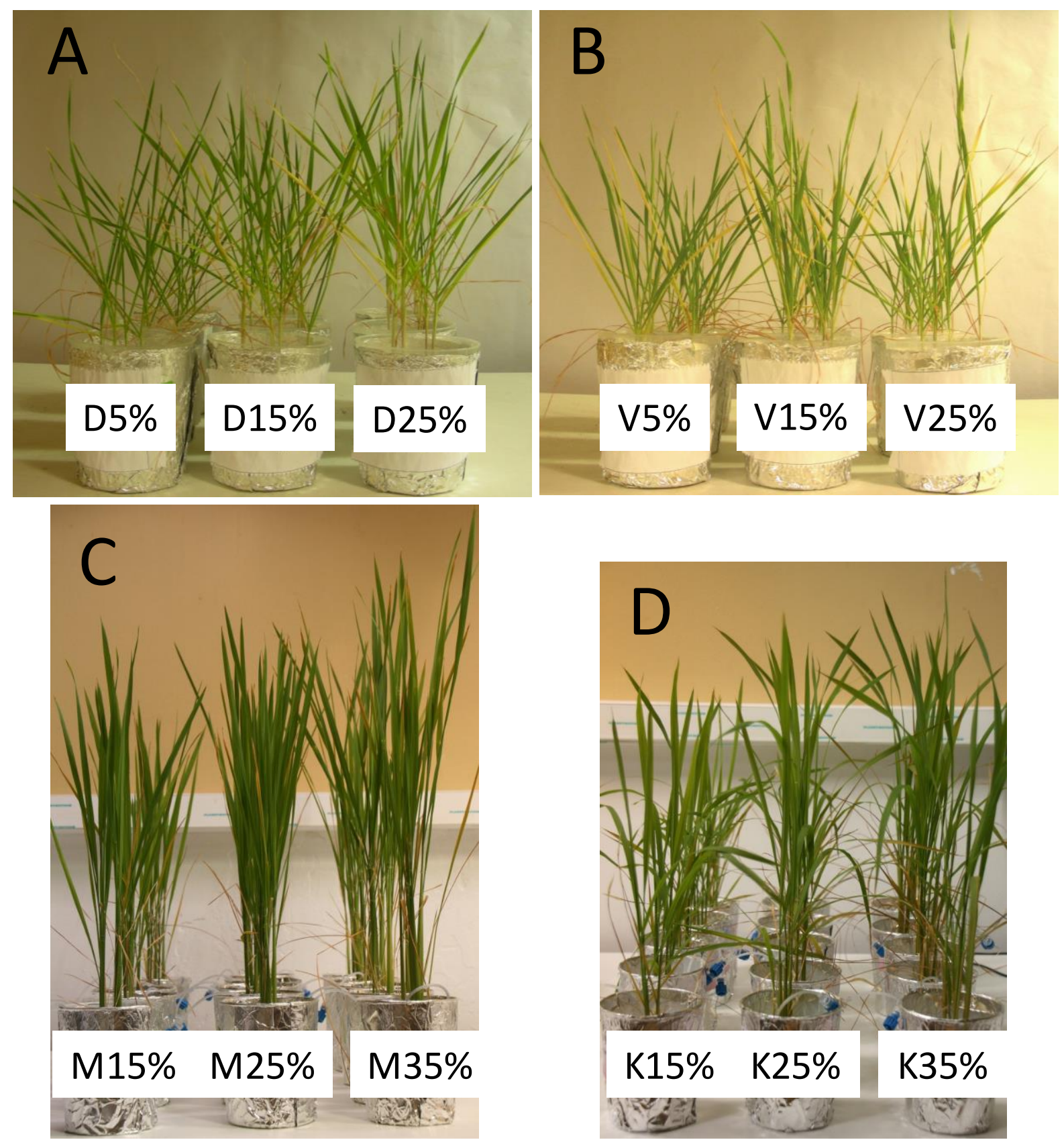

420 
$421 \quad$ Figure 2

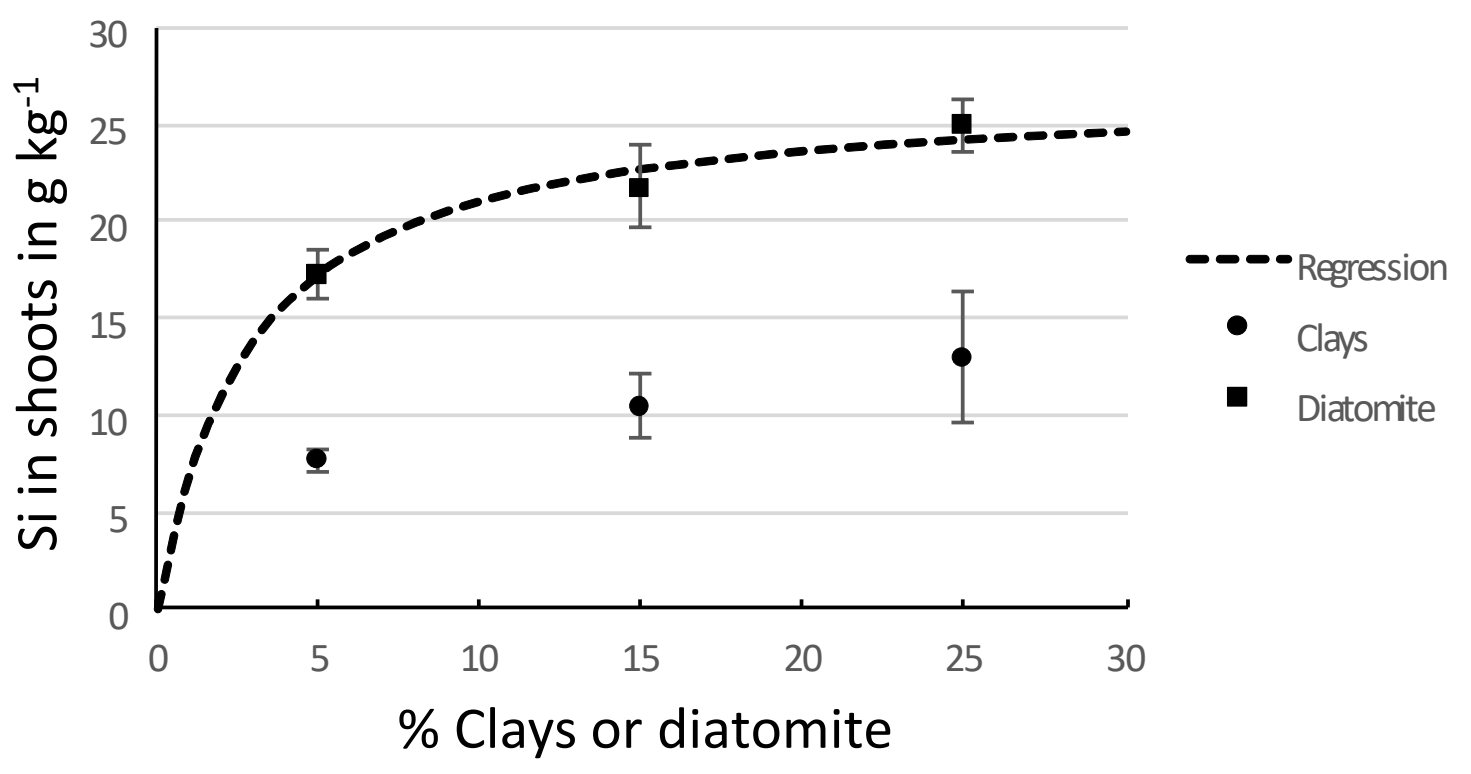

422

423 


\section{$424 \quad$ Figure 3}

425
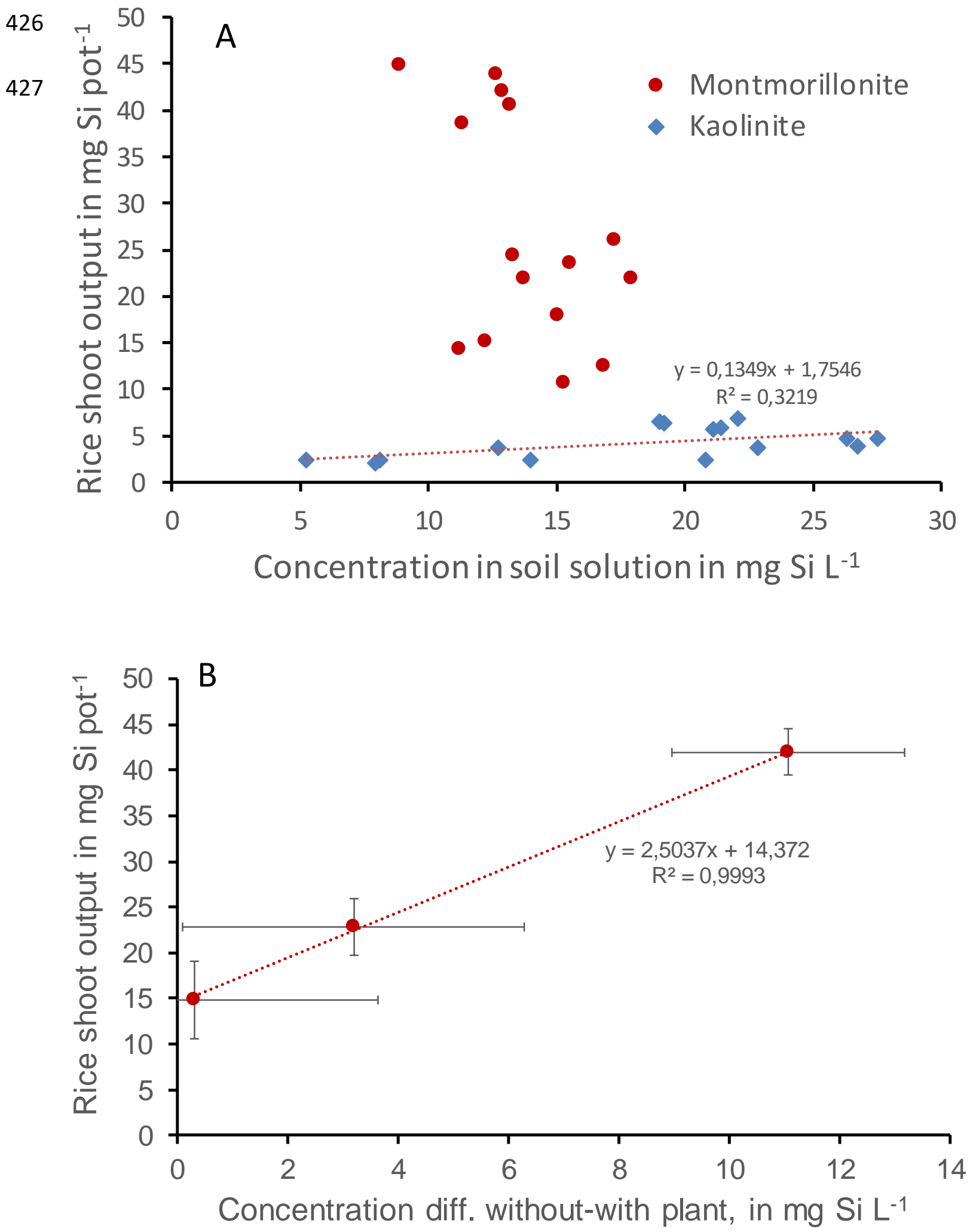